\title{
Natural vertical transmission by Stegomyia albopicta as dengue vector in Brazil
}

\author{
Cecílio, AB. ${ }^{\mathrm{a} *}$, Campanelli, ES. ${ }^{\mathrm{a}}$, Souza, KPR. ${ }^{\mathrm{a}}$, Figueiredo, $L B .{ }^{\mathrm{a}}$ and Resende, MC. ${ }^{\mathrm{b}}$ \\ ${ }^{a}$ Ezequiel Dias Foundation, Molecular Microbiology and Virology Lab \\ Rua Conde Pereira Carneiro, 80, Gameleira, CEP 30510-010, Belo Horizonte, MG, Brazil \\ ${ }^{b}$ National Health Foundation, Entomology Lab \\ Rua Rio de Janeiro, 1200, Centro, CEP 30160-041, Belo Horizonte, MG, Brazil \\ *e-mail: alzira@funed.mg.gov.br
}

Received January 30, 2007 - Accepted April 24, 2007 - Distributed February 28, 2009

\begin{abstract}
The mosquito Stegomyia albopicta is among the most important arbovirus vectors in the world, particularly for Dengue viruses. Their natural history suggests that biologically these viruses are highly adapted to their mosquito hosts and they were most likely mosquito viruses prior to becoming adapted to lower primates and humans. As well as being maintained by transmission among susceptible humans, Dengue viruses may also be maintained by vertical transmission in mosquitoes during inter-epidemic periods. The larvae and mosquitoes of Stegomyia albopicta were used to identify the vertical transmission of the dengue virus in nature and to confirm the vectorial capacity concerning the Dengue virus type 2 infection. The minimum infection rate concerning S. albopicta infection with the Dengue virus was 1:36.45. In Brazil this was the first time that high minimum infection rates of vertical transmission of $S$. albopicta were detected in this species.
\end{abstract}

Keywords: Dengue virus, vertical transmission, Stegomyia albopicta, vectorial capacity.

\section{Transmissão vertical natural de Stegomyia albopicta como vetor de dengue no Brasil}

\section{Resumo}

O mosquito Stegomyia albopicta está dentre os mais importantes vetores de arbovírus do mundo, particularmente para o Dengue virus. A história natural sugere que biologicamente esses vírus são altamente adaptados aos seus mosquitos vetores e foram, provavelmente, os vírus que infectavam mosquitos antes de se tornarem adaptados a primatas não humanos e humanos. Além de serem mantidos entre os homens susceptíveis, os Dengue viruses podem também ser mantidos pela transmissão vertical em mosquitos durante os períodos interepidêmicos. As larvas e mosquitos da espécie Stegomyia albopicta foram utilizados para a identificação da transmissão vertical do vírus dengue na natureza e para confirmar a capacidade vetorial em relação à infecção pelo DENV-2 infection. A taxa mínima de infecção em relação à infecção do S. albopicta com o Dengue virus foi de 1:36,45. No Brasil, esta é a primeira vez que altas taxas de infecção mínima da transmissão vertical de S. albopicta foram detectadas nessa espécie.

Palavras-chave: Dengue vírus, transmissão vertical, Stegomyia albopicta, capacidade vetorial.

\section{Introduction}

The mosquito Stegomyia albopicta (Reinert and Harbach, 2005) is among the most important arbovirus vectors in the world, particularly for Dengue viruses (DENV) (Gratz, 2004). DENV are members of the genus Flavivirus. They are plus-sense ssRNA viruses that cause dengue in humans. Their natural history suggests that biologically these viruses are highly adapted to their mosquito hosts and they were most likely mosquito viruses prior to becoming adapted to lower primates and humans (Fontenille and Toto, 2001). Dengue viruses are comprised of four closely related but antigenically distinct serotypes, designated DENV-1, DENV-2, DENV-3 and DENV-4 (Joshi, 2002). The spectrum of illness ranges from unapparent, mild disease to a severe and

occasionally fatal hemorrhagic clinical picture (Johnson et al., 2002). DENV are transmitted to humans by Stegomyia mosquitoes and the two most frequent vector species are the peri-domestic and competitive $S$. aegypti and S. albopicta (Guzman and Kouri, 2002).

The microhabitats of $S$. albopicta larvae are mainly tree holes and a wide variety of containers including natural and artificial containers, although this vector prefers common forested habitats in suburban and rural areas. The eggs can survive desiccation for several months. The adult biology of $S$. albopictus is similar to that of the urban population of $S$. aegypti, a dengue and yellow fever vector (Gratz, 2004). S. albopicta was recorded in North America as early as 1972. Its presence was re- 
ported in Brazil in 1986, in the states of Espírito Santo (ES), Minas Gerais (MG), Rio de Janeiro (RJ) and São Paulo (SP) (Hawley et al., 1987). Recently S. albopicta has been found in 14 Brazilian states (Forattini, 1986).

S. albopicta shows aggressive anthropophilic behavior and a great adaptability to different habitats (Gomes et al., 1999; Miller and Ballinger, 1988). In addition to being maintained by transmission among susceptible humans, DENV may also be maintained by transovarial transmission in mosquitoes during interepidemic periods (Rodhain, 1995). These species have the possibility of naturally transmitting the serotypes 2 and 3 of DENV vertically (Hull et al., 1984). Serotype 1 of DENV was isolated from naturally infected larvae of S. albopicta in Campos Altos, Minas Gerais (Serufo et al., 1993). This mechanism could explain the survival of DENV during dry seasons. During the outbreak of 2000, a successful attempt was made to detect DENV infection in Stegomyia aegypti larvae collected from nature in Pompeu city, Minas Gerais state, Brazil. In Brazil, this was the first time that vertical transmission of DENV has been shown to occur in nature, using molecular detection to confirm this mechanism (Ibanez-Bernal et al., 1997). S. albopicta has been identified as a dengue vector in Asia, Japan, Indonesia, the Seychelles, Thailand, Malaysia (Lourenço-de-Oliveira et al., 2003).

In this study we could detect vertical transmission of DENV-2 in S. albopicta larvae and identify the importance of S. albopicta as a dengue vector in Brazil detecting the virus in mosquitoes.

\section{Material and methods}

\subsection{Larval and mosquitoes collections}

78 oviposition traps were placed weekly near the house of patients suspected or confirmed to be infected with Dengue virus in the Pampulha region of Belo Horizonte, Minas Gerais state in May, 2003. The oviposition trap consisted of a black plastic recipient filled with water and containing a carton paddle. Paddles were collected, and Stegomyia eggs were hatched in the insectary. Fourth stage Stegomyia larvae were identified up to the species level based on the morphology of scales at the base of the siphon and thorn in the thorax (Consoli and Oliveira, 1994). Pools of 50 larvae were stored in vials at $-80{ }^{\circ} \mathrm{C}$ until required.

20 ovitraps were placed in the Pampulha region in the same position where DENV infections were detected in larvae in this study. Paddles were collected, and Stegomyia eggs were hatched in the insectary. Fourth stage Stegomyia larvae were identified as described above. The field-collected S. albopicta larvae were reared to adults in double cages as a biosafe measure. Emerged adults were fed on $10 \%$ sugar solution, and 5 days after emergence, the adults were identified to species for confirmation, separated into females and males and frozen at $-80{ }^{\circ} \mathrm{C}$.

\subsection{RNA extraction}

From the larvae collected, pools with approximately 50 larvae were ground using sterile sand. The supernatant of the ground larval pool was used to extract RNA. From larvae reared to adults, 18 mosquitoes were used to extract viral RNA. The head of each mosquito was separated from the thorax-abdomen using a sharp razor. The head was ground using sterile sand and the supernatant was used to extract RNA. RNAs were extracted by a modified silica method (Boom et al., 1990). Briefly, the supernatant was treated with a lysis buffer containing guanidine isothiocyanate, Tris $0.1 \mathrm{M}$, EDTA $0.2 \mathrm{M}$, Triton X-100 mixed with sterilized silica. After centrifugation the sample was washed with a washing buffer containing guanidine isothiocyanate and Tris $0.1 \mathrm{M}$, followed by several washes with $70 \%$ ethanol and acetone. The material was resuspended in TE (TRIS $10 \mathrm{mM}$, EDTA $1 \mathrm{mM}, \mathrm{pH}$ 8.0) treated with RNAsin and maintained at $-80{ }^{\circ} \mathrm{C}$ until required.

\section{3. cDNA synthesis}

The cDNA synthesis was conducted in a $20 \mu \mathrm{L}$ reaction containing $20 \mathrm{mM}$ Tris- $\mathrm{HCl}(\mathrm{pH} \mathrm{8.4),} 50 \mathrm{mM} \mathrm{KCl}$, $2.5 \mathrm{mM} \mathrm{MgCl}_{2}, 10 \mathrm{mM}$ dithiothreitol, $1 \mathrm{mM}$ each of the four dNTPs, $50 \mathrm{pmol}$ of the anti-sense primer, $250 \mathrm{ng}$ of viral RNA in $5 \mu \mathrm{L}$ volume and $200 \mathrm{U}$ of reverse transcriptase enzyme (SUPERSCRIPT II RT, Invitrogen) at $42{ }^{\circ} \mathrm{C}$ for 50 minutes.

\subsection{PCR assay}

- PCR Control - Each reaction set was checked for contamination using negative control (all reagents included except template DNA). In addition to this negative control, for reactions using pools of larvae RT-PCR of a negative pool of larvae was included, and for reactions using isolated material, RT-PCR of cells not infected was included, and for reactions using mosquito heads, mosquitoes from a breeding colony DENV free was used. Each reaction set included a DENV-2 sample previously sequenced as a positive control either from isolated material or from larvae.

- Primers - One pair of primers was used in a first PCR assay followed by a semi-nested PCR assay using serotype specific primers according to Lanciotti et al. 1992.

- PCR assay - The PCR using $5 \mu \mathrm{L}$ of the cDNA was conducted in reaction of $50 \mu \mathrm{L}$ containing $10 \mathrm{mM}$ Tris- $\mathrm{HCl}$ (pH 8.8), $80 \mathrm{mM} \mathrm{KCl,} 2 \mathrm{mM}$ $\mathrm{MgCl}_{2} 0.01 \%$ gelatin, $80 \mathrm{mM}$ of each of the four dNTPs, 50 pmol of each primers and 2 units of Taq DNA polymerase (Invitrogen). The thermal cycle used was that recommended by Lanciotti et al. 1992 using an annealing temperature of $58^{\circ} \mathrm{C}$.

- Semi-nested PCR - The semi-nested PCR was assayed using the same conditions of the first PCR assay. About $1 \mu \mathrm{L}$ of the first PCR was used as a template for the semi-nested PCR. The thermal 
cycle used was that recommended by Lanciotti et al., 1992 using an annealing temperature of $60{ }^{\circ} \mathrm{C}$.

- Detection of amplified DNA - $10 \mu \mathrm{L}$ of the semi-nested PCR amplified DNA underwent electrophoresis on a silver stained $8 \%$ poliacrylamide gel electrophoresis (PAGE).

\section{Results}

A total of 12.491 eggs were collected from 78 ovitraps from the Pampulha region in Belo Horizonte city in May, 2003. The number and percentage of hatching of S. aegypti and S. albopicta are given in Table 1 .

After hatching, a total of 163 pools of larvae of Stegomyia sp. were analyzed. 76 pools were positive for DENV showing a minimum infection rate of 1: 45,81 for Stegomyia sp. From a total of 72 pools of S. albopicta larvae processed as fourth stage larvae, 33 pools were positive for DENV-2, 2 were positive for DENV-1 and DENV-2 and 37 were negative for DENV. The minimum infection rate concerning $S$. albopicta infection with DENV was 1:35,45 (Table 2).

The adult mosquitoes were obtained by rearing in the laboratory larvae collected from 20 ovitraps placed in areas with confirmation of transovarial transmission of DENV in S. albopicta larvae (results not shown). The mosquitoes were then tested for DENV infection. 18 Stegomyia albopicta mosquitoes were selected in order to be tested for DENV infection. From this group, 7 mosquitoes were females and 11 were males, with 4 females and 4 males positive for DENV-2 infection.

\section{Discussion}

In the year of 2003, there were 324,512 reported cases of dengue in Brazil. 618 reported cases were of dengue hemorrhagic fever (DHF) with 33 deaths among these patients (Pan American Health Organization, 2003). In the same year there were 22,781 reported cases of dengue in Minas Gerais state. Belo Horizonte city notified a total of 1,557 reported cases (Prefeitura de Belo Horizonte, 2005). The Pampulha region was responsible for $239(15 \%)$ of the total number of reported dengue cas- es from the 9 regional districts (Barreiro, Center-south, East, Northeast, Northwest, North, West, Pampulha and Venda Nova). Pampulha represents the second region in terms of number of dengue cases, being behind only the northeast region (667 cases) of Belo Horizonte city. A percentage of $35,6 \%$ of $S$. albopicta hatching was registered in the Pampulha region, which represents a significant population of this species in an urban area.

Among public health authorities in the infested countries, there has been much concern that S. albopicta would lead to serious outbreaks of arbovirus diseases ( $S$. albopicta is a competent vector for at least 22 arboviruses), notably dengue (all four serotypes) more commonly transmitted by $S$. aegypti. Results of many laboratory studies have shown that many arboviruses are readily transmitted by $S$. albopicta to laboratory animals and birds, and have frequently been isolated from wild-caught mosquitoes of this species, particularly in the Americas (Reinert and Harbach, 2005).

In Brazil, dengue outbreaks have been associated with $S$. aegypti, and the role of $S$. albopicta in virus transmission in nature remains to be confirmed (Schatzmayr, 2000). The results of Lourenço-de-Oliveira et al., 2003 showed that Brazilian S. albopicta were as efficient as the North American population in being infected with dengue and yellow fever viruses in the laboratory.

In this study we developed a rapid, specific diagnostic tool, RT-PCR, for the detection and typing of DENV in larvae and adult mosquitoes in populations collected from nature. Our RT-PCR is a sensitive method capable of detecting the viral RNA in a single mosquito sample and typing DENV. Therefore it could be used to monitor the infection rate of infection with higher precision. The method could be applied to an active epidemiological surveillance program in order to identify the circulation of DENV in a region. The technique was used to detect DENV-2 in S. albopicta salivary glands as we used smashed heads to molecularly identify the presence of the virus in these glands. If the salivary glands of $S$. albopicta are integral to the transmission of the dengue virus, it might be hypothesized that they are highly efficient producers of infectious virions and capable of producing high titers of virus in the presence of less demonstrable antigen than other infected tissues of the

Table 1. Total number of collected eggs and percentage of hatching of Stegomyia aegypti e Stegomyia albopicta.

$\begin{array}{lcc}\text { Number of eggs collected } & 12,491 & \text { Percentage of hatching } \\ \text { Number of larvae identified } & 3,482 & 27.9 \\ \text { Number of Stegomyia aegypti larvae } & 2,241 & 64.4 \\ \text { Number of Stegomyia albopicta larvae } & 1,241 & 35.6\end{array}$

Table 2. Minimum infection rate.

\begin{tabular}{cccc}
\hline Stage examined & Positive pools/tested pools & Total number of larvae & Minimum infection rate \\
\hline Larvae & $76 / 163$ & 3,482 & $1: 45.81$ (Stegomya sp.) \\
Larvae & $35 / 72$ & 1,241 & $1: 35.45$ (S. albopicta) \\
\hline
\end{tabular}


mosquito. These data confirm the vectorial competence of $S$. albopicta in transmitting DENV-2 in the field remembering that genetic differences between $S$. albopicta populations through the country might exist (Consoli and Oliveira, 1994).

Thus, it seems that $S$. aegypti is the species involved in propagating the disease to epidemic proportion. This difference between the two species in vectorial capacity and competence could be explained by their oral susceptibility to Dengue viruses and feeding behavior (Chung and Pang, 2002). In the Americas, the introduction of S. albopicta has been associated with a decrease in the abundance of S. aegypti (Barrera, 1996; Khin and Than, 1983). Typically, S. albopicta prefers suburban and rural areas where it breeds in natural containers.

The occurrence of transovarial transmission of DENV-2 by Stegomyia aegypti in nature was demonstrated from the isolation of dengue virus from naturally infected mosquito larvae showing a minimum infection rate of 1:2,067 for DENV-2 (Sabin, 1952). Natural transovarial transmission of DENV-4 by S. aegypti was demonstrated from adult mosquitoes reared in the laboratory from eggs collected in Trinidad reporting a minimum infection rate of 1:1,855 for DENV-2 (Hull et al., 1984). The results of laboratory experiments described above with $S$. aegypti showed a very inefficient minimum infection rate. However we found a minimum infection rate for DENV-2 of 1:35,45 which indicates that transovarial transmission of dengue DENV by $S$. albopicta could provide a mechanism of maintenance of DENV when continuous mosquito breeding is interrupted. The transovarial transmission was confirmed by the detection of DENV-2 in male mosquitoes hatched from eggs which were collected in nature and reared in controlled conditions.

Transovarial transmission of DENV by Stegomyia could play an important role in the survival of these viruses in nature. Even low minimum infection rate might be sufficient to maintain the virus during dry seasons or during periods when insufficient numbers of mosquitoes are present to maintain the circulation of DENV in susceptible hosts. The minimum infection rate demonstrated in this study would appear more than sufficient to assist in the maintenance of DENV in nature.

While $S$. albopicta is less important than $S$. aegypti as a vector of DENV to man on a worldwide basis, it has been blamed as the principal vector in major outbreaks such as those in Japan during World War II (Metselaar et al., 1980) and Seychelles (Rosen et al., 1983). S. albopicta is predominantly rural in distribution but is also prevalent in urban areas especially in the absence of $S$. aegypti. S. albopicta is frequently associated with $S$. aegypti, as observed in different parts of the world. Some observations from regions where S. albopicta was recently introduced suggest it tends to supplant $S$. aegypti (Hobbs et al., 1991).

This is the first report of transovarial transmission and vectorial capacity of S. albopicta in Brazil concern- ing DENV-2 infection with molecular confirmation. Since $S$. albopicta shows susceptibly to DENV-2, vectorial capacity and occurrence of transovarial transmission of DENV-2, we can presume that the present expansion of this species is a threat to dengue control in Brazil specially using the same strategies as used for S. aegypti control.

Acknowledgements - E.S. Campanelli received a graduate scholarship from PUC-MG, research grant FIP01/2003.

\section{References}

BARRERA, R., 1996. Competition and resistance to starvation in larvae of container-inhabiting Aedes mosquitoes. Ecol. Entomol., vol. 21, no. 2, p. 117-127.

BOOM, R., SOL, CJA., SALIMANS, MMM., JANSEN, CL., WERTHERIM-VAN DILLEN, PME. and VAN DER NOORDA, J., 1990. Rapid and simple method for purification of nucleic acids. J. Clin. Microbiol., vol. 28, no. 3, p. 495-503.

CONSOLI, RAGB. and LOURENÇO DE OLIVEIRA, R., 1994. Principais mosquitos de importância sanitária no Brasil. Rio de Janeiro: Editora Fiocruz. p. 190-196.

CHUNG, YK. and PANG, FY., 2002. Dengue virus infection rate in field populations of female Aedes aegypti and Aedes albopictus in Singapore. Trop. Med. Intern. Health, vol. 7, no. 4, p. 322-330.

FONTENILLE, D. and TOTO, JC., 2001. Aedes (Stegomyia) albopictus (Skuse), a potential new dengue vector in southern Cameroon. Emerging Infectious Diseases, vol. 7, no. 6, p. 1066-1067.

FORATTINI, OP., 1986. Identificação de Aedes (Stegomya) albopictus no Brasil. Rev. Saúde Publ. São Paulo, vol. 20, no. 3, p. 244-245.

GOMES, AC., BITENCOURT, MD., NATAL, D., PINTO, PZS., MUCCI, LF., PAULA, M.B., URBINATTI, R, AND BARATA, JMS., 1999. Aedes albopictus em área rural do Brasil e implicações na transmissão de febre amarela silvestre. Rev. Saúde Pública, vol. 33, no. 1, p. 95-97.

GRATZ, NG., 2004. Critical review of the vector status of Aedes albopictus. Med. and Vet. Entom., vol. 18, p. 215.

GUZMAN, M. and KOURI, G., 2002. Dengue: an update. The Lancet Infectious Diseases, vol. 2, no. 11, p. 33-42.

HAWLEY, WA., REITER, P., COPERLAND, RS., PUMPUNI, CB., and CRAIG Jr., GB., 1987. Aedes albopictus in North America: probable introduction in used tires from Northern Asia. Science, vol. 236, no. 4805, p. 1114-1116.

HOBBS, JH., HUGHES, EA. and EICHOLD II., BH., 1991. Replacement of Aedes aegypti by Aedes albopictus in Mobile, Alabama. J. Am. Mosq. Control Assoc., vol. 7, no. 7, p. $488-499$

HULL, B., TIKASINGH, E., DE SOUZA, M. and MARTINEZ, R., 1984. Natural transovarial transmission of dengue 4 virus in Aedes aegypti in Trinidad. Am. J. Trop. Med. Hyg., vol. 33, no. 6, p. 1248-1250.

IBANEZ-BERNAL, S., BRISENO, B., MUTEBI, JP., ARGOT, E., RODRIGUEZ, G., MARTINEZ-CAMPOS, C., PAZ, R., DE LA FUENTE-SAN ROMÁN, P., TAPIA-CONYER, R., 
AND FLISSER, T., 1997. First record in America of Aedes albopictus naturally infected with dengue virus during the 1995 outbreak at Reynosa, Mexico. Med. Vet. Entomol., vol. 11, no. 4, p. 305-309.

JOHNSON, BW., CHAMBERS, TV., CRABTREE, MB., BHATT, TR., GUIRAKHOO, F., MONATH, TP., AND MILLER, BR., 2002. Growth characteristics of chimerivax DEN2 vaccine virus in Aedes aegypti and Aedes albopictus mosquitoes. Am. J. Trop. Med. Hyg., vol. 3, no. 3, p. 260-265.

JOSHI, V., MOURYA, DT. and SHARMA, RC., 2002. Persistence of dengue-3 virus through transovarial transmission passage in successive generations of Aedes aegypti mosquitoes. Am. J. Trop. Med. Hyg., vol. 67, no. 2, p. 158-161.

KHIN, MM. and THAN, KA., 1983. Transovarial transmission of dengue 2 virus by Aedes aegypti in nature. Am. J. Trop. Med. Hyg., vol. 32, no. 3, p. 590-594.

LANCIOTTI, RS., CALISHER, CH., GUBLER, DJ., CHANG, GJ. and VORDAM, AV., 1992. Rapid detection and typing of dengue viruses from clinical samples by using reverse transcriptase- polymerase chain reaction. J. Clin. Microbiol., vol. 30 , no. 3 , p. 545-551.

LOURENÇO-DE-OLIVEIRA, RL., VAZEILLE, M., DE FILIPPIS, AMB. and FAILLOUX, AB., 2003. Large genetic differentiation and low variation in vector competence for dengue and yellow fever viruses of Aedes albopictus from Brazil, United States, and the Cayman islands. Am. J. Trop. Med. Hyg., vol. 69, no. 1, p. 105-114.

METSELAAR, D., GRAINGER, CR., OEI, KG., REYNOLDS, DG., PUDNEY, M., AND LEAKE, CJ., 1980. An outbreak of type 2 dengue fever in the Seychelles, probably transmitted by Aedes albopictus (Skuse). Bull. WHO, vol. 58, no. 6, p. $937-943$.
MILLER, BR. and BALLINGER, ME., 1988. Aedes albopictus mosquitoes introduced into Brazil: vector competence for yellow fever and dengue viruses. Trans. R. Soc. Trop. Med. Hyg., vol. 82, no. 3, p. 476-477.

PAN AMERICAN HEALTH ORGANIZATION, 2003.Number of Reported Cases of Dengue \& dengue Hemorrhagic Fever (DHF), Region of the Americans (by country and subregion). [cited 2005 Jan 15]. Available from: http://www.paho.org/ english/ad/dpc/cd/dengue-cases-2003.htm

PREFEITURA DE BELO HORIZONTE. Taxa de Incidência de Dengue por Distrito Sanitário e Ano de Ocorrência, 19962003. [cited 2005 Jan 14]. Available from: http://www.pbh.gov. $\mathrm{br} / \mathrm{smsa} /$ montapagina.php?pagina=bhdengue/vigilancia.htm

REINERT, JF. and HARBACH, RE., 2005. Generic and subgeneric status of aedine mosquito species (Diptera: Culicidae: Aedini) occurring in the Australasian Region. Zootaxa, vol. 887, p. 1-10.

RODHAIN, F., 1995. Aedes albopictus: a potential problem in France. Parassitologia, vol. 37, no. 2-3, p. 115-119.

ROSEN, L., SHROYER, DA., TESH, RB., FREIER, JE. and LIEN, JC., 1983. Transovarial transmission of dengue viruses by mosquitoes: Aedes albopictus and Aedes aegypti. Am. J. Trop. Med. Hyg., vol. 32, no. 5, p. 1108-1119.

SABIN, AB., 1952. Research on dengue during World War II. Am. J. Trop. Med. Hyg., vol. 1, no. 1, p. 30-50.

SCHATZMAYR, HG., 2000. Dengue situation in Brazil by year 2000. Mem. Inst. Oswaldo Cruz, vol. 95, suppl. 1, p. 179-181.

SERUFO, JC., MONTES DE OCA, H., TAVARES, VA., SOUZA, AM., ROSA, RV., JAMAL, MC., LEMOS, JR., OLIVEIRA, MA., NOGUEIRA, RMR. and SCHATZMAYR, HG., 1993. Isolation of dengue virus type 1 from larvae from Aedes albopictus in Campos Altos city, state of Minas Gerais, Brazil. Mem. Inst. Oswaldo Cruz, vol. 88, no. 3, p. 503-504. 